\title{
Electricity and Empire in 1920s Palestine under British Rule
}

\author{
Ronen Shamir
}

Elektrizität und das „Empire”: Palästina der 1920er-Jahre unter britischer Kontrolle

Der Beitrag untersucht die technischen und politischen Aspekte der frühen Elektrifizierung Palästinas unter britischer Herrschaft in den 1920er Jahren. Er betont dabei die zentrale Bedeutung von technischem, topographischem und hydrologischem Wissen der beteiligten Akteure für den Elektrifizierungsprozess. Eingebettet in den breiteren Kontext kolonialer Elektrifizierungsvorhaben zeigt die Studie, wie sehr die britischen Kolonialherren mit ihrem beschränkten Wissen der lokalen Gegebenheiten in Palästina sowohl der deutschen Konkurrenz wie auch den einheimischen Unternehmern hinterherhinkten. Entsprechend gelang es den Briten nur bedingt, den eigentlichen Elektrifizierungsprozess zu kontrollieren und mit ihren eigenen Entwicklungszielen in Einklang zu bringen. Auf Grundlage dieser Erkenntnisse hinterfragt der Beitrag die grundsätzliche Annahme, Elektrizität habe als Instrument kolonialer Machtausübung gedient.

Schlüsse/wörter: Elektrizität, Kolonialismus, Wasserkraft, Hydroelektrizität, Palästina, Technopolitik

This article examines some techno-political aspects of the early years of electrification in British-ruled 1920s Palestine. It emphasizes the importance of local technical, topographical and hydrological forms of knowledge for understanding the dynamics of electrification. Situating the analysis in a general colonial context of electrification, the study shows that British colonial rulers lagged behind both German firms and local entrepreneurs in understanding the specific conditions pertaining to electrification in Palestine. Subsequently, the study shows that the British had limited control of the actual electrification process and its declared/professed developmental purposes, thereby complicating assumptions about electrification as a tool of the Empire/tool of empire. Finding some similarities between the cases of electrifying Palestine and India, the article's findings may shed further light on the importance of micro-politics of knowledge for understanding the trajectory of electrification in the colonies.

\section{Purpose of Inquiry}

Electricity "is in many respects the foundational apparatus upon which the experience of modernity has been constituted since the late nineteenth century" (Boyer 2015: 531). Electricity furnishes the quintessential infrastructure, one that enables many other types of infrastructure. Access to the electric grid is considered to be taken for granted by many (although certainly not all). So much so that electric grids become transparent and 
disappear from view. Unless a power cut hits: "When they are functioning as intended, infrastructures tend to disappear into the background: they become invisible. [...] They become visible only when they break down" (Gupta 2015: 557). Accordingly, historical and scientific studies of electricity aim to make visible the impact of electricity on populations, places, nations, politics, culture, markets, and geographies (Headrick 1988; Kale 2014b; Marquez 2010; Phillip 2005; Pomeranz 2000; Prakash 1999).

Given the relationship between a steady source of electrical supply and the tendency of the infrastructure to be rendered invisible, we could have expected greater attention given to places where electricity fails most-as is often the case in the Global South and the post-colonies, where people routinely turn to generators in order to compensate for the breakdown of the grid. However reviewing social scientific scholarship on infrastructures in the colonies or other non-Western countries Sunila Kale comments that "in much of this scholarship, what is arguably the twentieth century's most vital technology-electric current-is largely absent" (2014a: 455). And yet this may be changing. Most recently, Timothy Mitchell and Anupama Rao edited a special issue on "Life of Infrastructure" in Comparative Studies of South Asia, Africa and the Middle East (2014: 435-548). And Dominic Boyer guest edited a special issue of Cultural Anthropology on "Anthropology Electric" (2015: 531-588).

The present paper builds upon such works and on other explorations of electricity and electrification in the colonial era. Responding to current debates about the implications of electrification, this paper focuses on a single case study. It explores a 1920s original process of electrification in Palestine under British rule after World War I. ${ }^{1}$ The focal point of this study is the basic fact that while the British Government of Palestine and the Colonial Office in London facilitated the process of electrification by political and legal means, they by and large lacked effective control over the actual technological, industrial, and ecological aspects of the process. The technology which had been chosen (thermal rather than the agreed upon hydropower), the equipment which had been bought (diesel engines and electrical equipment from Germany rather than British made ones), and the knowledge that had to be transferred all came from Germany's AEG (Allgemeine Elektricitäts-Gesellschaft) which planned, supervised, and executed the enterprise. As for what may be considered as the environmental aspects of the electrification process, the British government in both Jerusalem and London either neglected or lagged behind in understanding the hydrological and topographical aspects of the process, hence having only limited control over these aspects too. In contrast to accounts suggesting that the Colonial Office in London adopted a hands-off approach in respect to the ways and means of electrification in the colonies (Hoag 
2013), the case of Palestine clearly demonstrates its profound interest in the minute details of the process and yet also the persistent frustration of British officials with their inability to steer electrification in Palestine in ways consistent with their policies and preferences.

Thus a primary purpose of this paper is to investigate and theorize the links and interactions between electrification, colonial and imperial powers, and local conditions in the colonies. I am going to examine a colony's evolving electrical infrastructure within its general environment-that is, a certain acquired knowledge and understanding (or lack thereof) of the ecology in which electrification is embedded-that plays part in shaping the character and the direction of electrification. The argument here is that the deployment of such local knowledge of local conditions works both ways, and goes beyond merely shaping the concrete process on the ground. Yet, whereas many studies to date focus on the way politics and commercial interests shaped electrical infrastructures, my analysis also suggests the merit of understanding the process of electrification as one, which shaped politics and economies at the imperial core. The co-ability of local Palestinian entrepreneurs and German electric engineers to bypass the British Empire and its electrical industries may be telling-in a small way-a bigger story about its decline, or at least about its declining capacity to reap the benefits from rapidly expanding electric grids in its own colonies.

The next section of the article offers a brief overview of the literature that ties colonialism and electricity. The section which follows uses recent findings to offer a bird's-eye view of the increasingly weakening grip that England had on electrification in its overseas colonies and dominions. These two sections lay the ground for a ground-level view of the 'how' of electrification. One section analyses the case of Palestine in order to explore the role of local conditions in allowing German technology and knowledge to act as a main drivers of electrification in a British-ruled colony. A second section on electricity and water shows that local experts, who had familiarized themselves with the topographical, hydrological, and electric-supply needs of the population, aided the Electric Company in shaping electrification in ways that may have contradicted British interests. The final section relies on local notions offering a framework for analyzing the mutual interdependencies between technology, empires, and colonies. 


\section{Electricity and Colonialism: A Brief Overview}

Major works on the origins and diffusion of electricity focus on Europe and the United States, where electricity had been originally developed and eventually widely distributed as a source of energy. Thomas Hughes's (1983) Networks of Power: Electrification in Western Society 1880-1930 is widely regarded as a tone setter. Moving away from technological determinism and yet not simply seeking to replace it with social explanations, Hughes analyzed the trajectory of electricity as a "seamless web" of connections: politics and science, administrative and engineering concerns, inventors and investors, and geographical and topographical conditions. All these actors and conditions took part in establishing the evolutionary stages of electrification and determining its uneven development and rationalization in England, Germany and the United States (Hughes 1983: $14 \mathrm{f}$.). Other scholars took an even more decisive turn away from technological determinism. Mark Granovetter and Patrick McGuire analyzed the American electricity industry in terms of its "identifiable social networks," showing that "the way the electricity industry developed was only one of several possible outcomes, and not necessarily the most technically or economically efficient" (1998: 48; Platt 1991).

Also remarkable is the 'cultural turn' in the study of electrical infrastructures, premised upon the idea that "every new technology is a social construction and the terms of its adoption are culturally determined" (Nye 1990: 381). In methodological terms, this means that studies of electricity consider the expectations and experiences of its users. David Nye shows that in the United States electricity had been initially introduced into urban centers to facilitate a spectacle of modernity (most notably street light). And Ronald Kline shows that the spread of the electric grid from the city to the countryside in the United States led to cultural dialogues on the very meaning of 'urban' and 'rural': rather than unambiguously embracing electricity as the hallmark of progress, rural populations resisted, modified, and selectively adopted the new technology "into existing social patterns" (2000: 269). And studying the industrialization of light in France, Wolfgang Schivelbusch distinguished between "lighting of festivity" and "lighting of order," the former used and distributed for symbolic displays of progress, the latter for policing nighttime activities (1995: 137).

The cultural turn in the study of electricity links the production and provision of electricity to electricity's social distribution and usage. From this perspective, the distribution of electricity participates in the construction of space, the deployment of authority and modes of governance, and the creation and affirmation of social difference. However, this does not imply that electricity is just a means for transmitting the political or economic 
power of those who are behind the technology. Rather "the different ways in which populations, regions, and productive life were interconnected or isolated by an energy system shaped the very modes of government" (Mitchell 2014: 438), including the choice of technology, differential or preferential access, and the very ability to use electricity as an instrument of control (Rao ND 2015; Shamir 2013).

However at least until recently, little has been known about electrification in colonial and post-colonial settings compared to major works undertaken in the industrialized West. Global Electrification (Hausman et al. 2008) is a timely corrective, offering a comparative historical view that spans the globe from the late nineteenth century onwards, focusing on the policies and politics of imperial governments, the emergence of globallyoriented electric industries, and the emergence of a global financial network able to invest in and promote large-scale electrical works all over the world.

Hausman et al. (2008) give little attention to the actual social impact of electrification on the former colonies. The history of electrification in the colonies, as well as attention to issues of impact and meaning, is the domain of only a handful of scholars. Perhaps unsurprisingly, some of the studies in and about the colonies are quite in line with the cultural turn in the social study of electricity in general. First, in colonial settings the introduction of electricity also interacted with the local responses of farmers, industrialists and the general public to its utility, necessity, and symbolic value vis-á-vis alternative or traditional forms of energy (on India see Speyer 1915; on Syria, Lebanon and Palestine see Faris 1936).

Second, studies of electricity in the colonies also highlight the relationship between access to electricity and issues of inequality, marginalization, discrimination-but also empowerment (Winther 2008). Some studies are somewhat reminiscent of Schivelbusch's distinction between lighting for festivities and lighting for order, contextually adapted to a racial setting. In former Rhodesia (Zimbabwe) Moses Chikowero (2007) speaks of the power politics behind electrification, distributing light to homes of white settlers and streetlights for the policing of the black African population. In Nigeria, electricity performed a "source of pride to colonial regimes" and mainly reached the urban centers where Europeans lived (Phillip 2005: 49; also Showers 2011). In 1920s Dutch-ruled Indonesia, Susie Protschky noted the association of "light" (licht) and "enlightenment" (verlichting) in late colonial visual culture, and a subsequent channeling of electricity to "areas that had some of the highest density of Europeans and the longest histories of European settlement in the Indies" (2012: 3). In both British-ruled and German-ruled East Africa, Jonas van der Straeten notes electricity as "amenities for colonial settlers" and as a service that was "highly racialised 
in colonial urban planning" (2014: 1; 2015a: 275; 2015b). Such analyses of electricity are part of the broader perspective, which considers ethnic difference, specifically treating colonized natives as fundamentally inferior, as a constitutive modus operandi of colonialism (for instance, Steinmetz's 2007 study of the German overseas colonial empire).

Still an important debate among students of electricity in the colonies is situated precisely at the intersection between colonial studies and studies of technology and infrastructure. Daniel Headrick's studies (1981) have shaped and influenced a direction of inquiry that is premised on the notion of modern technologies and infrastructures as Tools of Empire. Focusing on colonial India, and not unlike Headrick, Gyan Prakash also deployed the technology-as-a-colonial-tool thesis. Prakash discusses the British technology grid: railways, roads, telegraph and telephone lines, and irrigation and hydro-electric projects, coming together as colonial instruments for consolidating authority, exploiting economic resources, and transporting wealth to the imperial center. Srinivasa Rao and John Lourdusamy add that the electric grid had been crucial to this infrastructural configuration: "Apart from being part of the 'grid', it also served as motive power to the 'technology grid' itself” (2010: 30). In a similar vein, a study of the origins of electrical supply in Calcutta found that "the model for the development of electricity in Calcutta was basically designed keeping in mind the interests of the colonial government" (Suvobrata 2015: 359). Heather Hoag (2013), offering an environmental history of British colonial Africa, also seems to espouse the tool-of-empire thesis, showing that development of hydropower and waterways mainly benefitted settlers' communities and colonial industries and agriculture.

In recent years, the technology-as-a-colonial-tool thesis has been modified and revised. Rao and Lourdusamy (2010), studying electrification in the Madras Presidency in India, distinguished between treating colonial rulers as drivers of and main beneficiaries of electrification and the role of local governments and commercial enterprises in shaping the process. While not entirely rejecting the colonial-tool thesis, Rao also shows how local ethno-political divisions lead to the creation of two separate electric grids (2010). Rao and Lourdusamy suggest that "in the initial years of the twentieth century, the colonial government did not fully realise the potential of electricity and decided to leave electricity to local governments and private agencies (both foreign and Indian)" (2010: 30). Comparing the early process of electrification in three Indian regions (Princely Mysore, Bombay Presidency, and Madras Presidency), Kale (2014a) finds that "rather than being governed according to any discrete logic of colonial governance, electric systems became terrains in which a variety of views about the proper role of the state in industrial transformation as well as the suitable means to 
promote economic development were elaborated" (2014a: 455). According to Kale, lacking a guiding logic and an "overarching design," British decision-making in the area of electrification resulted in "a heterogeneity of relations between state power and technology" (2014a: 455, 472).

This heterogeneity in the circumstances and complexities of electrification, in turn, suggests a conceptual departure from accounting for the introduction of new technologies and infrastructures with broad strokes; what we need is a grounded account that would localize the process and its implications for colonies and empires (Barak 2014). Ute Hasenöhrl and van der Straeten (2016, this issue), therefore suggest methods and perspectives for problematizing and challenging the classical narrative, moving away from a view of uninterrupted diffusion of capital and knowledge from the imperial core towards an understanding of the multilayered and contested movements of technology and knowledge that underlie the construction of infrastructures in the colonies and their relation to colonialism, the environment and local circumstances. Such recent developments in thinking about electricity and colonialism inform the present study as well.

\section{Britain's Electrical Short Circuits}

Germany's overseas colonial empire was short lived, lasting from 1884 until the end of World War I in 1918. During this time, Germany also emerged as an empire of electric technology. Berlin has been called the Elektropolis: "Two of the world's leading manufacturers of electric machinery, Siemens $\mathcal{E}$ Halske and AEG, had central offices and factories in Berlin and its immediate surroundings" (Hughes 1983: 177). By 1900, AEG became the largest manufacturer of electrical machinery in Germany, also financing, designing, and building power-stations and electric streetcar systems. German firms were involved in worldwide electrification, vigorously competing against other European and American firms with the backing of Deutsche Bank and German state diplomacy (Cin 2015). By 1903 AEG had reached an agreement with General Electric in the United States "to divide their world markets" (Hughes 1983: 179).

The expansion of German electric technology did not stop at the borders of the British Empire. Even prior to the outbreak of WWI, the British had not been competitive in the electrotechnical industry' (Hausman et al. 2008: 134); German, Swiss and American companies often enjoyed a stronger hold on electrification. In South Africa, the British registered Victoria Falls \& Transvaal Power Co. was owned by the German Siemens $\mathcal{E}$ Halske. In India, one study found it "a matter of regret" 
that England was surpassed in the electrification of the sub-continent, presenting data that showed that in the five most important public electric supply undertakings in India, "of 66,900 kilowatts of plant installed in these stations Switzerland has supplied 54,000 kilowatts, England only 7,500 kilowatts, and the United States 5,400 kilowatts of the prime movers, whilst Germany has supplied no less than 32,000 kilowatts, the United States 17,000 kilowatts, Switzerland 10,000 kilowatts, and England only 7,500 kilowatts of the electrical generating plant" (Speyer 1915: 598). The contractors for the Bombay hydroelectric Tata plan, one of India's biggest electric projects, included General Electric (powerhouse and transformers), Siemens (turbines and generators), and the Swiss company Escher, Wyss $\mathcal{E}$ Co (Dickinson 1915).

The British electrical industry also remained noncompetitive after the war. "For one of the world's most industrialised nations," writes Hoag, "British electricity sector lagged behind other nations such as Germany and the United States" (2013: 139). By the late 1920s German electrical manufacturers resumed global exports, with AEG, Siemens and the rapidly expanding Swiss manufacturer Brown Boveri E Cie. investing in electric utility companies all over the world. The late 1920s saw the age of big utility holding companies. In the United States, the American E Foreign Power holding company invested, managed, and provided technical advice to electric schemes all over South and Central America, China and India, sometimes replacing English firms, which had prior stakes in those countries. In Europe, the Belgian Sofina emerged as a global electrical giant, with investments and ownerships of electric power plants and grids in Europe, Asia and Africa; and the cooperation between Sofina, AEG, and the German holding company Gesfürel (Gesellschaft für elektrische Unternehmungen) symbolized "the renewed participation" of German firms in international business (Hausman et al. 2008: 153).

Accounting for Britain's weakness in the electricity markets, Hausman et al. (2008) stress not only the relative backwardness of its electrical manufacturing but also its slow response to the changing world of finance. Unlike financial institutions like Deutsche Bank, they write, "there was no bank in England of any size that would offer to finance a new proposition of any magnitude" (2008: 138). In the 1920s, in an effort to boost their trailing industries, the British Parliament passed the Trade Facilities Act. From then on, in return for governmental loan guarantees borrowing firms seeking to invest in electrical works and utilities were obliged to purchase materials from British industries (Shamir 2013: 119-121). A reference to the impact of the Trade Facilities Act is found in a study of the electrification of Nigeria under British rule. The implication of the policy of "imperial preferences," writes Phillip, "greatly affected most of 
the existing electricity undertakings and even the plan to establish new ones" (2005: 37). African British colonies like Nigeria, he writes, "were forced to purchase their required spare parts and high powered generating sets from British manufacturing industries instead of cheaper generating sets from Germany (Siemens \& Halske), Swiss (Brown Boveri), America (Corliss Valve Engine), Sweden (Allmänna Svenska Elektriska and Ericsson)" (2005: 39). Indeed, although American and European firms had penetrated almost any single national market for electricity around the globe, one could still find traces of British presence: Bellis and Morcom, Fraser $\mathcal{E}$ Chalmers, and Mirrlees Engines, Vickers electric products, Pauling and Co. electro-hydraulic equipment, Callenders Cable $\mathcal{E}$ Construction Co. wires and grids, and British Westinghouse, to name a few.

Still, it seems that measures such as the Trade Facilities Act only had a limited effect. The overall macro picture which emerges from the literature is that unlike its success in dominating and benefitting from infrastructures enabled by coal, steam engines, or the telegraph, Britain lost, in fact never established a firm enough foothold in projects of electrification. British electric industries lagged behind American and Continental competitors and this backwardness had been compounded by insufficient sources and frameworks of finance. The fuller implications of Britain's weak hold on electrical supply are perhaps most vividly clarified by looking at the relative increase of electric imports and decrease of steam imports to India in the pre-War period. H. R. Speyer (1915) showed that electrical imports grew from roughly $£ 155,000$ to $£ 200,000$, while steam plummeted from roughly $£ 800,000$ to $£ 300,000$ between 1907 and 1912. These figures tell a dramatic story given the scholarly consensus about the importance of coal and its related technology of steam-powered engines to Britain's imperial might during the 19th century.

In England, the Water-Power Committee Report raised serious concerns about the future prospects of the Empire as early as 1922. The Report acknowledged the end of the coal era, warning that "the Empire's position in water-power development at the present time compares unfavourably with that of its commercial competitors", urged the harnessing of waterpower for electricity and the urgent need to develop corresponding knowledge and technologies (Clerk \& Gibbson 1922, cited in Hoag 2013: 141). In other words, the rise of electricity and Britain's late response to this rise, may well have anticipated the decline of empire. With this macro-perspective in mind, the next section follows a process of electrification on the ground, mainly focusing on the case of Palestine. 


\section{The Jaffa Electric Company}

The British Army entered Jerusalem in December 1917 and completed the conquest of Palestine from the crumbling Ottoman Empire toward the end of World War I in 1918. A Military Administration had been in charge of the country until July 1920, when it was replaced by a civil administration. ${ }^{2}$ Upon conquest, the British army immediately began to repair and expand the country's railway infrastructure. At that time, the main line of this infrastructure had been the Jaffa-Jerusalem railway, built at the end of the nineteenth century by a French company under concession from the Ottoman Government. Plans and debates over whether to electrify this line and how to finance such a project were to become an important issue in years to come.

In November 1917, Foreign Secretary Arthur James Balfour (1848-1930) wrote to Walter Rothschild, $2^{\text {nd }}$ Baron Rothschild (1868-1937), a leading Jewish-British Zionist, and thus addressing the Zionist Organization of Britain. Widely known as the Balfour Declaration, he promised that "His Majesty's Government view with favour the establishment in Palestine of a national home for the Jewish people, and will use their best endeavours to facilitate the achievement of this object" (Gilbert 2007: 27). This British foothold in the Middle East received international backing through colonial agreements with France and later the League of Nations. In 1922 the Council of the League of Nations issued the "British Mandate for Palestine." The Mandate fully embraced the Balfour Declaration, transforming the promise to facilitate a Jewish National Home into an international obligation. The Mandate reiterated the commitment to promote the necessary conditions for establishing a Jewish National Home in Palestine, along with a general obligation to develop the country for the benefit of all its inhabitants. The commitment to promote a Jewish National Home was particularly significant considering the demographic profile of the country at the time: 643,000 Arabs and 84,000 Jews according to a 1922 census (8:1 ratio). The Mandate recognized the Zionist Organization (headquartered in London) as the public body with which the British would consult and cooperate in matters affecting the establishment of the Jewish National Home (Article $4 \&$ 5). Article 11 entrusted the Government of Palestine to develop the country and, to that end, to "have full power to provide for public ownership or control of any of the natural resources of the country or of the public works, services and utilities established or to be established therein."

One of the earliest decisions of the newly instituted British civil administration was to grant Pinhas Rutenberg (1879-1942) - a capitalist entrepreneur of Russian descent who had been backed by Zionist institu- 
tions and financiers in London and Jerusalem-exclusive rights to electrify Palestine. ${ }^{4}$ These rights were delivered through two concessions: The Auja (Arabic for Hebrew Yarkon) Concession for the Jaffa District (signed on September $\left.12^{\text {th }} 1921\right)$ granted a soon-to-incorporated company (the Jaffa Electric Company) exclusive rights to generate, distribute, and sell electricity in the District of Jaffa, for the provision of light in the (mostly Arab) town of Jaffa and the smaller adjacent settlement of (predominantly Jewish) Tel Aviv, for water supply, and for irrigation in surrounding agricultural settlements. To that end, the concession also granted water rights to the Electric Company, an issue that became a source of dispute in years to come. The second concession, which had not been formally signed until March $5^{\text {th }} 1926$ was called the Jordan Concession and granted exclusive rights to electrify Palestine and Trans-Jordan as a whole (Shamir 2013: 15). The decision to grant Rutenberg the electricity concessions for Palestine was largely in line with the colonial office's policy of electrification by means of local initiatives in individual colonies by private entrepreneurs. In British colonial Africa, for example, this policy was conceived to suit the idea of governing "on the cheap" and had been translated into granting concessions to mining companies (Hoag 2013: 44). Both concessions were premised on the provision of energy by hydroelectric power. The Auja Concession mandated the construction of a hydroelectric station on the Auja River near Jaffa, and the Jordan Concession mandated the construction of a hydroelectric station in the intersection of the Jordan and Yarmuk rivers south of the Lake of Galilee in the country's north (Reguer 1995). The present study focuses on the trajectory of the earlier, smaller, and yet original Auja Concession.

The grant of the concessions worked as an economic medium for advancing imperial policies: they were perceived by the British as a way to promote the Jewish National Home by economic, rather than political means; the theory being that electricity would contribute to prosperity, hence attracting more Jewish immigrants and strengthen their overall social capacities. At the same time, and somewhat at odds with the former aspiration, the British treated the electrification of Palestine as a demonstration of their commitment to the general development of Palestine, an economic benefit which could also yield the pacification of Jewish-Arab ethnic-national tensions (Shamir 2013). However, no formal and open tender preceded the decision to grant the concession to the Zionist-backed Jaffa Electric Company. Unavailable sources of finance or unwillingness of British firms to invest in electric schemes, already noted before the war in the case of India (Speyer 1915), continued post-war all over the world (Hausman et al. 2008), including Palestine. It seems that British companies and investors did not consider the electrification of Palestine as 
potentially lucrative (Smith 1993: 132). The possibility of Arab-Palestinian entrepreneurs vying for such a concession had not been given any serious thought.

Unlike the benefits that the would-be Jewish National Home derived from electrification, the general developmental aspiration was significantly frustrated. Palestinian-Arabs expressed strong opposition to the electrification scheme on grounds that it would allow the Zionists to obtain "a stranglehold on the economic life of Palestine and Transjordania." Indeed Jewish domination of the scheme had been clear and, in years to come, increased the economic advantages of the Jewish minority over those of the Arab majority of Mandate Palestine. Although the Jaffa Electric Company was nominally a "free standing company" which was "financed with British Capital" (Hausman et al. 2008: 216), it was essentially a Zionist enterprise: financial backing came almost exclusively from Zionist organizations and Jewish philanthropists, including the London-based Jewish Colonial Trust and the Palestinian Jewish Colonization Association (funded by Rothschild). Rufus Isaacs, $1^{\text {st }}$ Marquess of Reading (1860-1935) sat on the board of the Palestine Electric Company (registered 1923) as the representative of several British trust associations, and other notable British Jewish investors, including Sir Alfred Mond, $1^{\text {st }}$ Baron Melchett (1868-1930) and Michael Nassatisin (1876-1931). The Anglo-Palestine bank, the major financial arm of the Zionist movement, was also involved in financing the scheme. ${ }^{6}$

\section{The Auja Concession}

The administrative routine in the Colonial Office for authorizing concessions was based on a three-phase process: principled political approval, negotiation of legal terms, and expert opinion on the technical and financial feasibility of proposed projects.

The political decision to grant the Auja Concession to the Jaffa Electric Company had been worked out and agreed upon through letters, reports, and telegraphs that circulated between the Government of Palestine in Jerusalem led by High Commissioner Herbert Samuel (1870-1963), who actively lobbied for the electrification plan, and officials in the Colonial Office in London under the guidance of a supportive Winston Churchill (1874-1965), then Secretary of State for the Colonies. The legal aspects of the concessions were negotiated between the lawyers of the concessionaire and the attorneys who advised the Colonial Office and the Government of Palestine. The contractual details-which in 1927 were incorporated into 
Palestine's Electricity Concessions Ordinance-established hydroelectricity as the chosen technology, sanctioned and scheduled the construction of a powerhouse on the Auja River, guaranteed the powers of the Government's Public Work Department to oversee and validate the technical aspects of the process of electrification, established a scale of rates to be charged for different levels of electric usage, and elaborated on matters such as possible disputes concerning electric-meters. However, as Kale observed in her study of electrification in India, neither the concessions nor the legislation that followed revealed any "discrete logic of colonial governance" (2014a: 455).

Once the political decision had been made, the Colonial Office instructed its lawyers to work out the legal aspects of the concession "in the form used in Colonies and Protectorates."7 After the legal details of the scheme had been in place, final approval only depended on the third component of concession-granting, that is, a technical-feasibility report. Here again, the procedure was similar to the one in other British colonies. In matters of electricity concessions, the Colonial Office consulted the experts of the electrical engineering firm Preece, Cardew E Ryder.

Yet something out of the ordinary had taken place regarding Palestine. At least one official in the Colonial Office seemed to have noticed the asymmetry between the political-legal phases and the technical phase of the process, and pondered over the haste: "Is not this concession a matter upon which we should obtain the opinion of Messrs. Preece, Cardew and Ryder as we have done in other cases, for instance the Freetown Sierra Leone Electric Light concession? I am inclined to think that we should." This communication went unanswered. On July $2^{\text {nd }} 1921$, less than three months before the concession's scheduled approval, the Colonial Office announced that it was prepared to authorize the Auja Concession. On August $9^{\text {th }} 1921$ the consulting engineers addressed the matter of the Auja Concession in a formal letter to the Colonial Office: "The Auja basin concession was, as you know, not referred to the consulting engineers," and "the terms of the Auja basin concession were practically agreed by you and Mr. Rutenberg before referring to us and do not admit of revision." ${ }^{9}$ In response, the Colonial Office formally asked the consulting engineers to deliver a report on the Auja hydroelectric plan. A week later, on August $31^{\text {st }}$ 1921, twelve days before the final deadline, the consulting engineers submitted a seven-page report on the Auja plan. ${ }^{10}$

In order to understand the implications of the asymmetry between the political and legal speedy approval of the concession and the belated technical report, a consideration of the Auja electrification plan is in order. The plan was to raise an out-of-repair small dam (which served an old flour mill) by one meter so that the water level would reach 6.90 meters 
above sea level. The plan was then to excavate a 2.6 kilometer canal that would create a tail-race of the flowing water at sea level. Allowing for loss, the head available for use in the water turbines would be 6.25 meters. At this point, the water would drive turbines and alternators installed at the nearby flour mill. The calculation was that normal conditions in dry weather would generate a flow of 8.5 cubic meters per second and that this would suffice for producing 350 kilowatts of electrical energy. From the hydroelectric powerhouse, electricity would then be transmitted by 6,000 Volt high-tension cables to the Jaffa District, supplying electricity for irrigation, water pumps, private and public lighting, and industrial enterprises. Five transformer substations would be placed in Tel Aviv and Jaffa, where energy would be transformed into low tension.

The consultants' report reviewed the plan and stated that the engineers had been presented with four documents: a general scheme, a survey of the Auja River, a sketch of dams, and a hydroelectric power station plan. The report first referred to the scheme's hydraulic aspects, based on "automatic discharging siphons and spillways for dealing with flood water" and on designs for "sluices and screens to control the flow of water to the power house." The report then commented on the electrical aspects. Referring to the estimates of the expected kilowatt demand, it noted that if demand exceeded 350 kilowatts, a diesel engine would be required as a supplement. It also stated that there was "nothing to criticise" in respect to the proposed distribution system and that the plan as a whole looked entirely "modern." The report concluded that there was "considerable evidence" of the thoroughness and care invested in the plan: "We are of the opinion that the proposed scheme is a practical one and that it has possibilities of being a sound commercial success."11

Nevertheless, the consulting engineers also reflected upon their own limitations. The basic approval of the plan notwithstanding, the report acknowledged a weak link between expert opinion and local knowledge: "We have no knowledge of the district served" the engineers stated, and "we have however no local knowledge as to possible engineering difficulties which might arise and no means of checking [the] figures" [emphasis added by author]. ${ }^{12}$ Yet on September $1^{\text {st }} 1921$ Churchill sent a telegram to High Commissioner Samuel, informing him that the consulting engineers had produced a favorable report. ${ }^{13}$

This lack of knowledge is not per se surprising. As Hoag (2013) shows in her analysis of hydropower in British colonial Africa, colonial ignorance of local conditions was widespread in the 1920s, in particular regarding river flows and seasonality. However, this colonial deficiency is important for complicating the electrification as a tool-of-empire thesis and the notion that laissez faire policies best served colonial interests. In the case of 
Palestine, conceding the development of electricity to a private company with its proper knowledge of local conditions, allowed the latter to undermine and frustrate, rather than promote the policies and preferences of the Colonial Office in London and the British Government of Palestine.

The technical details of the Auja hydroelectric plan retained their consistency throughout the process of approving the concession. The Preece, Cardew $\mathcal{E}$ Ryder report recorded the specifications of the proposed plan and in turn these specifications were embedded in articles 7 and 8 of the Auja Concession. Still, as we shall shortly see, the Auja hydroelectric plan never materialized. In its stead, the Jaffa Electric Company built a diesel-fuelled powerstation elsewhere. And it is precisely the matter of local knowledge of local conditions, or the absence thereof, that sheds light on what eventually transpired.

\section{Then We Take Berlin}

Like in other British colonies, the model for electrifying Palestine was based on the devolution of authority to provincial governments or local town councils that would contract the concessionaire for electric supply. In India "the earliest investments in electric development came from private companies that obtained government licenses to generate and distribute electricity within cities and larger towns" (Kale 2014a: 467). This piecemeal model of electrification resulted in the situation that by 1937 only 143 out of 517 Indian municipalities had access to electricity (Tinker [1954] 1968: 191). Moreover, this model allowed for local political and economical discussion. In the Madras Presidency, it led to discussions about the importation of "better and cheap electrical technology from Germany, the US and Switzerland [...] as opposed to the costlier ones from England" (Rao \& Lourdusamy 2010: 30).

Not unlike India and other colonies where the British model of electrification transferred authority to local governments (on colonial Africa see Showers 2011), Palestine's Auja concession mandated electric supply to the District of Jaffa, at that time consisting of the predominantly Arab town of Jaffa and its neighboring-and by far smaller-Jewish town of Tel Aviv. Working with such a model in mind, and without informing the British authorities, the would-be concessionaire entered into negotiations with the Tel Aviv town council even before the concession had been approved.

On April $4^{\text {th }} 1921$, five months before signing the concession, members of the Council of Tel Aviv Township convened to hear the opinions of a local electrical engineer on the matter of electrification. The engineer 
Table 1 Comparison of English and German price for electrical machinery (Israeli Electric Company Archive: 2371-1-85)

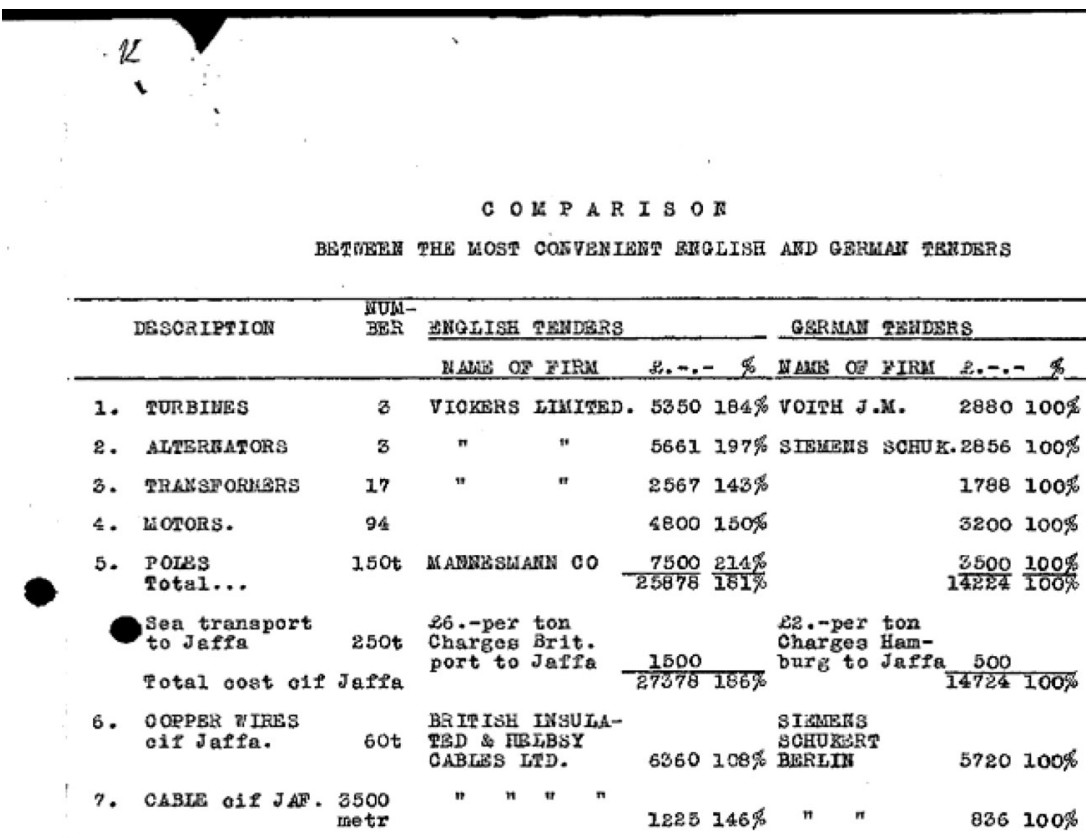

commented on the proposed Auja scheme and was adamant in stating that: "Electric supply by means of the Yarkon [Auja] River will definitely not be sufficient [...] because both Jaffa and Tel Aviv are undergoing rapid development, and electrical power will be needed in order to establish many new factories" [emphasis added by author]. He went on to suggest an alternative: "I am not saying that the Auja plan is unimportant [...] but from what we know from various European countries it will be possible to increase the energy if we install a spitzen kraftwerk [hydroelectric power plant]." The Council concluded a few days later: "We need a special powerhouse for light and power, and we hereby request Mr. Zeidner [the electrical engineer, R. S.] to prepare a response to Rutenberg and to let him know that we are in great need for electricity."14

In a follow-up meeting, the Council was informed that "Rutenberg expressed a principled consent to build us a diesel power-house before he goes on to execute the Auja plan" [emphasis added by author]..$^{15}$ The council of Tel Aviv gathered for another meeting on February $5^{\text {th }} 1922$, when the Auja Concession had already been approved. The Chairman's account in that meeting was revealing. Already in the summer of 1921, he said, the council entered into "successful negotiations with the German firm AEG." After the concession had been granted: 
I travelled with Rutenberg to Germany in order to see what needs to be done. We started in Berlin where we negotiated with Mayorchek, the chief engineer of AEG, about how to set up the installation. Mayorchek explained to Rutenberg that the power which is needed is greater than that which may be generated by the river [...] and in consultation with AEG we concluded that we need to build a $1000 \mathrm{HP}$ engine based power-house.

Upon hearing the opinion of the $A E G$ engineer, Rutenberg changed his mind "and gave up": "We decided to build a power-house for the District of Jaffa with $1000 \mathrm{HP}$," he concluded, "and we already ordered two 500 horsepower diesel engines that will arrive in five months' time [...] and then I went to the factory of Deutz in Köln and realised that it would take 7-8 months for the engines to arrive" [emphasis added by author]. ${ }^{16}$

Both a local electrical engineer in Tel Aviv and a German AEG engineer in Berlin had serious reservations about the potential of the Auja waters to produce sufficient electrical energy. In fact, for people with local knowledge the verdict that the Auja River was not powerful enough could not have been very surprising. After all, the Auja River was not very much of a river. In reality it came much closer to what others would have called a creek, and it was practically common knowledge that the Jordan River was "the only considerable flow of water in the country" (Faris 1936: 280). The concessionaire had also been convinced that his plan was technologically unsound. Only the British, equipped with the opinion of their own consultants as to their insufficient local knowledge concerning the scheme, remained in the dark. And once the decision to build a diesel-fuelled powerhouse had been reached, providing $A E G$ in Berlin with the knowledge and needs of the (Jewish) locals in Tel-Aviv, the decision to rely on German equipment and expertise had also been established.

In August 1921, before the Auja Concession had been granted and without disclosing the decision to switch from one technology to another, Rutenberg prepared a "Comparison of Different Tenders for Machinery and Materials" (see Table 1). ${ }^{17}$ The document was divided into seven chapters, each with a detailed comparison of British and German providers for one of the seven essentials on the scheme's shopping list: turbines, alternators, transformers, motors, poles (tubular), copper wires, and cables. The comparison included the prices offered by German firms such as $A E G$, Voith, and Siemens, and British firms such as the English Electric Company and Vickers Limited of London. When it came to hydroelectric turbines, the difference in price between German turbine manufacturer Voith and British manufacturer Vickers stood at 164 percent in favour of Voith. British firms fared slightly better in pricing copper wires, showing only an eight 
percent difference in favour of Siemens over British Insulated E Helsby Cables Ltd. Moreover, the comparison showed that the cost of shipping from Hamburg to the port of Jaffa was considerably lower than the cost of shipment from British ports. In an urgent letter sent to Churchill, Rutenberg further explained that

I collected data regarding the cost of the machinery and materials required for my project. I found that the lowest English tender was $98 \%$ in excess of tenders made in Germany, when the Mark was 1800-2000 to the $£$ sterling. Although German prices have since risen, yet the drop in the value of the Mark still maintains a difference of considerably more than $100 \% .^{18}$

The first two 500 horsepower diesel engines for the relocated powerhouse for the Jaffa District were bought from Deutz in Köln. Other vital machinery such as generators, transformers, control switchboards, and numerous other components were ordered from $A E G$ (Naor 2003). In addition to the equipment know-how was imported too. $A E G$ acted as a consultant, and the Jaffa Electric Company opened a contact office in Berlin. The AEG team in Tel Aviv consisted of six full-time consultants by mid-1923, headed by Herteuch. The technicians and engineers of the Jaffa Electric Company were instructed "to follow the monitoring instructions of AEG" in all aspects of the process including assigning another AEG expert, Stadi, "to oversee the wiring of Ajami [in Jaffa]."

Knowledge of local conditions, bringing to the fore the interests of Jewish settlers in Tel Aviv (also foreseeing the need to provide electricity to a nascent Jewish industry), had been linked to the newly acquired climatic and topographical knowledge of German electrical engineers. While the connections between Jerusalem and London created the political and legal foundations of the concession, it was the grounded link between Tel Aviv and Berlin that determined the technology and technical aspects of the works. In short, the initial phase of electrifying Palestine had been firmly placed in German hands.

\section{British Response: Losing the Imperial Grip on Grids}

Anticipating a political fallout in London, Rutenberg wrote Chaim Weizmann (1874-1952), head of the Zionist Executive Committee in London, and received assurances that he should opt for the more competitive prices "without consideration of any other factors." ${ }^{20} \mathrm{He}$ also wrote to Churchill, 
acknowledging his awareness that "the placing of orders in Germany might lead to undesirable political consequences in this country."21 In its communications with the Colonial Office the Jaffa Electric Company relied on British imperial logic in order to justify the decision to turn to German products. It reasoned that the promotion of a Jewish National Home through the economic development of Palestine required the lowest possible rates for electricity, in turn guaranteed by the lower prices of German equipment. Moreover, sound economic development would also help pacify Arab-Jewish relations. Yet the communication to Churchill did not disclose the technological-topographical conditions that prompted the decision to rely on diesel-fuel generating power and to relocate the power house. A political explanation had been offered, alleging that Arab land owners in the Auja River's basin asked for exorbitant prices for their properties. Here again, local conditions played a part, this time in the form of convincing the Colonial Office that the turnaround in the way the concession was to be realized could be justified in political and legal terms.

While the Colonial Office reluctantly authorized the change of location and technology for the powerhouse, it could not avoid the political fallout. In the summer of 1922, the reliance of the Jaffa Electric Company on $A E G$ made news in the London press, drawing criticisms and prompting Members of Parliament to raise the issue. In public, Churchill vigorously defended the political decision to grant the concession to a Zionist-backed entrepreneur. Behind closed doors, he instructed the Colonial Office to stop the concessionaire from buying equipment in Germany (Smith 1993: 122) and in response, the Jaffa Electric Company made assurances that it would buy materials and equipment in England as long as the difference in prices did not exceed ten percent (Shamir 2013: 45).

The price of British-tendered copper wires was only eight percent higher than that of German wires. Neatly falling within the ten percent difference, copper wires were indeed the single item on the initial shopping list that had been bought in England. It was only later, when the Jaffa powerhouse was already fully operational and the electric grid was undergoing rapid extensions, that the Jaffa Electric Company considered the purchased of two transformers in England. When in late 1925 one of the 500 horsepower Deutz engines broke down, the Jaffa Electric Company purchased for the first time a 250 as well as a 300-horsepower British Mirrlees diesel engine. Shortly afterward the company ordered from England an 1,125 horsepower Fraser \& Chalmers engine, which was expected to become operational in 1926. By then electrification was in full swing.

Apart from general expressions of dissatisfaction and perhaps some tacit pressure measures the Trade Facilities Act represented a more specific effort to promote British electric industries (Hausman et al. 2008; 
Phillip 2005). In 1926 the Palestine Electric Company (which absorbed the Jaffa Company to assume the larger-scale all-Palestine Jordan Concession) sought to secure the British government's loan guarantee for its planned hydroelectric project. The Trade Facilities Advisory Committee, in charge of authorizing such loans, initially declined to approve it, citing the decision not to electrify the Jaffa-Jerusalem railway line as a major reason for losing faith in the necessity for large scale electrification in Palestine.

The events that followed also tell something important about local knowledge and imperial designs. Recalling the British government's discontent earlier in the decade on learning that German equipment had been used for the electrification of Jaffa, the Palestine Electric Company now reasoned with the Colonial Office that a similar situation applied to the Jordan Project as well: German equipment was significantly cheaper than British equipment, and only a government-guaranteed loan under the Trade Facilities Act, which would legally bind the company to buy electrical equipment in England, would tie the hands of the board of directors who might otherwise opt for cheaper German tenders. The already mentioned influential British Zionist Sir Alfred Mond also lobbied the Advisory Committee, lecturing it on local conditions: Palestine had changed, he wrote, and the electrification of the railways had become unimportant. Instead, demand for electricity had been soaring because of new demand from Jewish industry in Tel Aviv. ${ }^{22}$

His reasoning fell on sympathetic ears at the Colonial Office. It communicated to the Advisory Committee "how disappointed [the Secretary of State] was to learn of your committee's unfavourable decision," reiterated the "utmost importance" of the loan, and "regretted" that the Committee had not attached "sufficient importance to changing conditions." 23 On September $23^{\text {rd }} 1926$, the Advisory Committee reversed its earlier decision and approved a government-guaranteed loan of $£ 250,000$ to the Palestine Electric Company. This time around communications concerning local knowledge about local conditions, combined with the threat of turning once again to German electrical firms had their impact.

\section{Electricity, Water Rights and Hydrology}

Knowledge of local conditions, or lack thereof, also played an important part in the ability of the Electric Company to control and shape the water regime of the Auja River and its vicinity. Here again, in matters specifically related to what we would nowadays consider as environmental concerns, the argument of this paper is also reaffirmed: a colonial government unable 
to generate sufficient local knowledge, resulting in loss of control over the process of electrification and its broad implications.

The Electric Concession, anticipating the construction of a hydroelectric powerhouse, granted the Electric Company the rights to use the waters of the Auja River for both energy generation and irrigation. Although the plan to build such a hydroelectric powerhouse had never been realized the Electric Company still held to its water rights and could, if it so chose, to utilize the river's waters for electrically generated irrigation. These untapped water rights of the Electric Company became a source of dispute in 1925, when the government announced a plan to pump 20,000 cubic meters of water a day from the Auja to supply Jerusalem with water. The Electric Company objected, in spite of the fact that it had yet to develop any comprehensive irrigation scheme. Nonetheless the company solicited its own expert report and raised an ecological argument at the service of financial interests:

The growth of the population in the Jaffa region will necessitate in the near future the withdrawal of large amounts of water from the Auja for the drinking and domestic purposes of this population and any further withdrawal for outlying districts would considerably reduce the water available for irrigation, which is of vital importance for the Jaffa region. ${ }^{24}$

The Electric Company's report also offered calculations of its projected lost revenues. The government's Director of Public Works produced a different report, suggesting that the water in the Auja would suffice for both irrigation as well as water supply for Jerusalem. Yet not unlike the case of London's electrical engineers discussed above, the director admitted that he had no adequate and reliable topographic and hydrological maps at his disposal and that his calculations were performed under time constraints. ${ }^{25}$ Officials in the Colonial Office in London were therefore reluctant to let the matter be decided on scientific grounds and instead sought to reach a compromise with the company concerning the amount of water the government could use for the water supply of Jerusalem.

This water dispute between the government and the Electric Company is telling because at its bottom was the limited topographical and hydrological knowledge at the government's disposal, allowing the Electric Company to put up figures and arguments that were hard to verify. As aforementioned, colonial knowledge of local hydrological conditions was also scarce across British colonial Africa-and possibly elsewhere too. The 1922 Report of the British Water-Power Committee pointed out this "dearth of reliable information" (cited in Hoag 2013: 141) that slowed and undermined Britain's ability to benefit from the developments in water-driven turbine technol- 
ogy. And while the Water-Power Report drove the rise of hydrological investigation and hydropower surveys from the 1920s and 1930s onwards (Showers 2011), throughout the 1920s Palestine was not included in and thus did not benefit from these surveys. Yet again, this lack of local knowledge worked to the detriment of colonial interests and problematizes the approach of electrification as a "tool of empire."

Developments in years to come shed further light on this matter. In 1930, the Hope-Simpson Report claimed to have discovered the reason behind the company's slowness in using the Auja waters for irrigation. It established that the profits generated by the company from feeding electrically powered water pumps in water wells outdid its inclination to develop a large-scale irrigation scheme. The commission complained that the greater amount of the Auja water flowed into the sea because the Government "parted with the irrigation rights" and in general described a localized and privatized system of water rights (Hope-Simpson 1930: 83, 149). Analyzing the nonexistent water regime of Palestine, the HopeSimpson Report also noted that the government failed to produce sufficient topographic and hydrologic knowledge (Trottier 1999). In contrast, Zionist institutions became interested in developing such knowledge given that the British regulation of Jewish immigration to Palestine explicitly tied this to the availability of irrigable land as a measure of the absorptive capacity of the country (Reichman et al. 1997; Alatout 2009). Taking this into consideration, science-based hydropolitics became a site of Zionist activity well ahead of the government, as Jewish hydrologists began to study and survey the country's underground and surface water. Once again German expertise proved useful: this time through hydrologists who immigrated to Palestine from Germany in the mid 1920s and began to publish scientific reports and submit detailed memoranda to Zionist bodies (Gross 1987; Alatout 2009). Mandatory Palestine lagged behind; hence the Hope-Simpson Report urged the British administration to conduct an all-Palestine hydrographic survey. It critically analyzed the consequences of granting an exclusive concession to the Palestine Electrical Company, pointing out its dire effects on the government's ability to shape Palestine's water regime. Several years later, the Peel Royal Commission of Inquiry on Palestine found similar dire consequences and reasons for regret regarding the water rights granted to the Palestine Electric Company in the Jordan Valley (Peel 1937). For the purposes of this article, however, suffice to conclude that also in ecological matters, and at least in the formative years of electrification, it was the Electric Company, aided and guided by German experts, that had substantive advantages over the Colonial Government in shaping electrification and its multiple political, technical, and environmental consequences. 


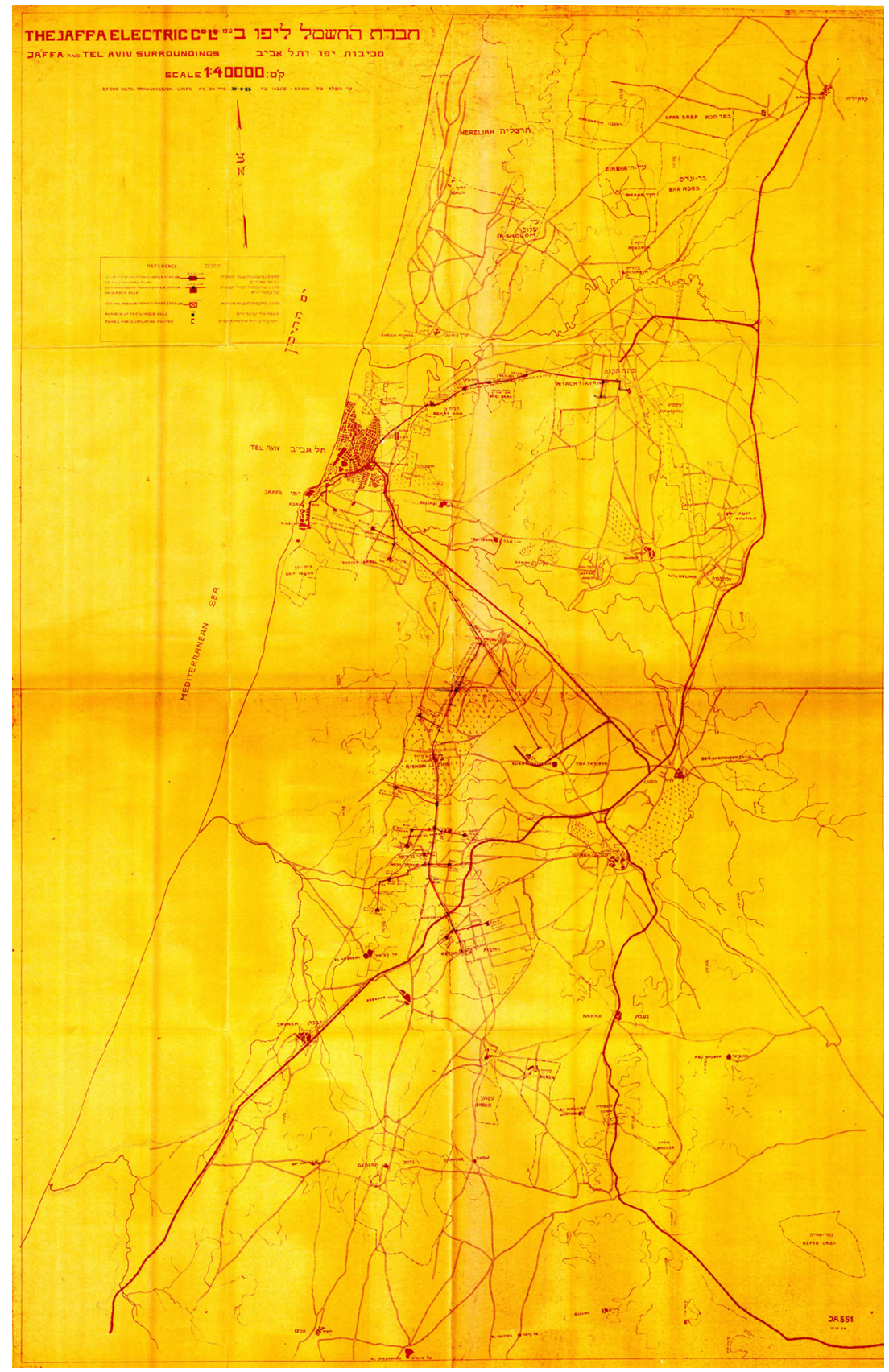




\section{Lessons: Imperial Logics and Local Conditions}

The electrification of Palestine, rather than being a colonial tool serving the British Empire, and rather than contributing to the economic development of the country as a whole, greatly benefitted the Zionist colonization of economic and political power in Palestine. Barbara Smith concluded that electrification under British auspices was "fundamentally a Zionist project" (1993: 119). Indeed electrification contributed to the growing economic gap between Arabs and Jews (Shamir 2013). Of course, this outcome may in and of itself be considered to have served British imperial policy goals. And in this sense the study of Palestine's electrification, situated within the general debate about technology and empire, does not fully depart from the technology-as-a-colonial-tool thesis (Headrick 1981). However, the effort in this article was to supplement macro level analyses of Britain's lost opportunities in the area of electricity with a nuanced localized account of the process. In so doing, and in an effort to contribute to the still small number of studies that explicitly address the relation between infrastructures, colonialism, and the environment (Hasenöhrl \& van der Straeten 2016), the study also seems to problematize the electrification as a "tool of empire" thesis.

Alongside the principled issues of prices and finance, references to local knowledge and local conditions kept appearing at crucial moments throughout the process of electrifying Palestine. Specifically, local conditions seem to have played an important part in establishing the supremacy of German electrical products over English ones. Regarding India before World War I Kale found that-not unlike post-war Palestine-"there was some anxiety among British engineers that in the race to electrify India, British electric equipment manufacturers were losing out to continental (German and Swiss) and American firms" (2014a: 457). Kale found traces of such anxiety in an article written by H. R. Speyer, an English electrical engineer who visited India in the 1910s. His analysis of Indian electrification had been published in the Journal of the Institution of Electrical Engineers and is illuminating for present purposes (Speyer 1915).

Speyer counted several reasons as to why Britain had been losing the electrical field to Continental and American competition. The first issue was lack of British capital for investment in the electrical field, and the reluctance of British firms to invest in India's electrification. The second issue was that English electric industries were maladjusted to the standardization of voltage between 220-6,000. This, Speyer claimed, allowed better opportunities to European competitors because it incurred higher costs on British firms that had to "cover special constructions;" further, such adjustments tended to delay the times it took to deliver equipment (Speyer 1915: 
599). A third general explanation was that British firms priced electrical equipment on the basis of F.O.B (Free on Board) or C.I.F (Cost, Insurance and Freight). In both cases, the price did not include the seller's responsibility to the proper assembly and maintenance of the equipment. When the use of a technology is in its "infancy," as was the case with electricity in India, such prices were "quite useless" to the buyer (Speyer 1915: 598).

Yet Speyer also offered an analysis at the level of local conditions. The main problem he identified was the poor grasp of English manufacturers and suppliers of electrical equipment on local conditions; "something else must be offered," he wrote, British firms "must be prepared to send out to the country their very best power men [...] and to undertake the electrification of mills and factories from $\mathrm{A}$ to $\mathrm{Z}$ and not against F.O.B or C.I.F prices" (1915: 598). One immediate consequence of lacking experts on the ground was that electrical equipment had been misassembled or malfunctioned. In turn, this damaged the confidence of Indian industrialists and mill owners in the new technology, augmenting their suspicion of electricity and bolstering their resistance to the replacement of steam engine technology. He argued that it was necessary "for an engineer to be on the spot to nurse carefully any new electric power installation during the first 18 months or two years, or as a matter of fact until such a time as the mill owner or his engineers have gained complete confidence in the working of the plant" (Speyer 1915: 597).

Augmenting the problem of failing British equipment was the lack of engineering knowledge about local climatic conditions that seriously impacted the correct installation and maintenance of engines, turbines, and wiring. India was hot and humid, Speyer explained, necessitating careful adjustments in respect to issues such as condensation and insulation. Unlike British firms, foreign competitors seem to have been gaining advantages by being aware of local conditions and by developing their local knowledge: "Continental makers are fully alive to the conditions under which electrical plant has to work in India, and have spent both time and money in experiments before deciding on the standardisation of plant intended for export to a tropical country" (1915: 599). Foreign companies, in short, had both teams on the ground and a practice of acquainting themselves with local knowledge.

Speyer's observations in India bear a striking resemblance to the present account of electrification in Palestine. British manufacturers had little understanding of the demand for electricity in Palestine (which soared dramatically during the 1920s and 1930s), and British experts and consultants to the Colonial Office had little understanding of the hydrological, climatic and topographical conditions pertaining to the proposed hydro electric scheme on the Auja River. At the same time, the British model of devolv- 
ing authority to regional or municipal authorities contributed to the latter's greater impact on both the choice and use of technology. German $A E G$, once contacted by the municipal entrepreneurs of Tel Aviv and their local electrical engineer, were quick to grasp local conditions and to offer a technological alternative. Also enjoying competitive advantage in prices, $A E G$ offered a package deal that included a team of engineers on the ground, overseeing the installation of equipment and the outlaying of the grid. Insufficient or partial understanding of local conditions also contributed to the ability of the Jaffa Electric Company to circumvent the concession's specifications about the location of the powerhouse and its hydroelectric technology. Citing political reasons for not being able to purchase lands necessary for the construction of the powerhouse on the Auja River, the company was able to effectively avoid disclosing the technical reasons for the change. In hydrological matters as well, the Electric Company seems to have enjoyed knowledge and data that allowed it to shape the methods of water supply and irrigation in the region.

The combination of a model that relied on local governments contracting for electricity, insufficient understanding of local conditions by the London-based British consulting engineers, lack of interest by British electrical manufacturers, and an assertive German firm that had been quick to grasp opportunities and to install itself on the ground, resulted in a weak British hold over electrification. The feeble British responses to its loss of competitiveness, more often expressed in protests and complaints than in aggressive countermeasures, seems to have sealed the British Empire's enduring lagging behind Continental and American firms. Leaving much to be decided at local level, but relatively ignorant of local conditions, allowed the alliance between Jaffa Electric Company, the Tel Aviv local council, and German $A E G$ to determine the character of electrification while pushing British firms to the margins.

As has been illustrated in the introduction to this volume (Hasenöhrl \& van der Straeten 2016), country-specific case studies and comparative research on the intersection of infrastructures, colonialism, and the environment only just begin to emerge. The methods and findings of this study indicate the relevance of focusing on the micro-politics of techno-science within this prospective domain of research. Here, the probing into the local forms of knowledge and networks of actors, which are grounded in experience, the immediate access to and familiarity with specific conditions and circumstances, seem to have yielded some new insights concerning the processes of electrification in the colonies. Situating technical and hydrological expertise in this context show that transfers of local knowledge to the imperial core, or failing to do so, had significant implications for the ability of empire to achieve or maintain a competitive advantage in the 
matter of electrification. The knowledge flow concerning local conditions from the colonies to the imperial centers involved ruptures, discontinuities, bureaucratic mistakes, and deliberate distortions that shaped policies and practices maladjusted to local conditions (Cohn 1996; Shamir \& Hacker 2001). Local knowledge and local conditions, and not only macroeconomic factors, seem to have contributed to the fact that unlike Britain's command of coal and its infrastructures in the nineteenth century, the electrical revolution did not yield similar results for Britain's power in the twentieth century.

\section{Endnotes}

1 This article relies on archival materials electrifying Palestine's Jaffa Region in the early 1920s (Shamir 2013). Unless a secondary source is cited, data is from the British National Archives (BNA), the Israeli Electric Company Archive (ECA) and Tel Aviv Municipality Historical Archive (TAHA). For the specific purposes of this article, this primary data is situated in relation to studies of electricity in other colonies, some in Africa and most notably India. However, this article does not offer a comparative study but rather an in-depth analysis of a particular case, possibly opening up the field for future comparisons.

2 Unlike many other British colonies Palestine had been ruled through the internationally sanctioned instrument of a Mandate (like Syria and Lebanon under French rule; for more elaborate distinctions between British forms of colonial rule, specifically regarding the issue of hydropower see Hoag (2013: 145)). However, this difference does not warrant the treatment of Palestine as an entirely different case of colonial rule. Concretely, Palestine's model of electrification had also been similar to other British colonies. For more sources on this issue see Shamir (2013: 14).

3 URL: http://avalon.law.yale.edu/20th_century/palmanda.asp (last accessed: 04.03. 2016).

4. Rutenberg occupies a unique and controversial position in the history of Zionism in Palestine. An outspoken capitalist, he often bitterly clashed with the Zionist establishment. Shaltiel's (1990) excellent political biography of Rutenberg describes him as authoritarian, charismatic and flamboyant. Rutenberg struck good relations with both Palestine's High Commissioner Samuel and Winston Churchill at the Colonial Office. He enjoyed considerable clout among British officials. Leo Amery wrote about him as "that rather remarkable personality [...] though a Jew [...] he stands somewhat outside the Zionist organization [...]," letter from Leo Amery to Foreign Secretary Anthony Eden, 26.06.1937, CO 733/337/2.

5 BNA PREM1/24, June 22 ${ }^{\text {nd }} 1923$, “The Palestinian Arab Case." For a detailed account of the impact of electrification on the economic and political divide between Arabs and Jews in Palestine see Shamir (2013).

6 For full lists of shareholders and their voting rights see: ECA A-0475-20, A-047555 and A-0475-90. Siegfried Eliezer Hoofien (1881-1957), an influential Dutch-born banker, acted both as general manager of the Anglo-Palestine bank that financed the Jaffa Electric Company as well as a director of the company on behalf of the Jewish Colonial Trust (a large shareholder), see: CO 733/151/6.

7 BNA CAOG 14/109, Instructions of John Shuckburgh to Burchells, solicitors to the Colonial Office and the Crown Agents. 
BNA CAOG 14/109 and BNA CO 267/627/1-8.

9 BNA CAOG 14/109, August $9^{\text {th }} 1921$, Memorandum from Preece, Cardew $\mathcal{E}$ Ryder to Mr. Vernon at the Colonial Office.

10 BNA CAOG 14/108, The Preece Report.

11 BNA CAOG 14/108, The Preece Report, p. 2-5.

12 BNA CAOG 14/108, The Preece Report, p. 6, para. 9.

13 BNA CAOG 14/108, Telegram no. 342.

14 TAHA 283b [box 422], protocols $21-23$ of council meetings on April $4^{\text {th }}, 10^{\text {th }}$ and $14^{\text {th }}$ 1921.

15 Ibid.: Protocol 21, 233-241.

16 TAHA, 283b (box 422), February $5^{\text {th }} 1922$, Protocol 77, 564-567.

17 ECA 2371-1-85.

18 ECA 2371-1/0043, Letter of December $21^{\text {st }} 1921$.

19 ECA 0352-111-251, Instructions of Rutenberg April-May 1923.

20 ECA 2371-1/0086, Letter of August $17^{\text {th }} 1921$.

21 ECA 2371-1/0043, Letter of December $21^{\text {st }} 1921$.

22 BNA CO 733/129/13, August $6^{\text {th }} 1926$, Letter from Alfred Mond to William Plender, Chairman of the Trade Facilities Advisory Committee.

23 BNA CO 733/92, Exchanges of May-June, 1925.

24 BNA CO 733/96, August $12^{\text {th }} 1925$.

25 BNA CO 733/116, August $18^{\text {th }} 1926$, Report of Department of Public Works.

\section{References}

Alatout, Samer 2009. Bringing Abundance into Environmental Politics. Social Studies of Science (39:3): 363-394

Barak, On 2014. Three Watersheds in the History of Energy. Comparative Studies of South Asia, Africa and the Middle East (34:3): 440-453.

Boyer, Dominic 2015. Anthropology Electric. Cultural Anthropology (30:4): 531-539.

Chikowero, Moses 2007. Subalternating Currents: Electrification and Power Politics in Bulawayo, Colonial Zimbabwe, 1894-1939. Journal of Southern African Studies (33:2): 287-306.

Cin, Duygu A. 2015. The European Competition to Electrify Istanbul in the Early Twentieth Century. International Journal of Turkish Studies (21): 95-116.

Clerk, Dugald and Arnold H. Gibbson 1922. Water Power in the British Empire - The Reports of the Water Power Committee. London: Constable \& Co.

Cohn, Bernard 1996. Colonialism and Its Forms of Knowledge: The British in India. New Jersey: Princeton University Press.

Dickinson, Alfred 1915. The Bombay Hydro-electric Scheme. Journal of the Institution of Electrical Engineers (53): 693-714.

Faris, Basim 1936. Electric Power in Syria and Palestine. Beirut: American University of Beirut Press.

Gilbert, Martin 2007. Churchill and the Jews: A Lifelong Friendship. London: Simon \& Schuster.

Granovetter, Mark and Patrick McGuire 1998. The Making of an Industry: Electricity in the United States. In: Michel Callon (ed.). The Laws of the Markets. Oxford: Blackwell: 147-173.

Gross, Nachum 1987. Absorbing Academic Immigrants in the 1920's and Hydrological Research. HaZionut (12): 127-140 (Hebrew). 
Gupta, Akhil 2015. An Anthropology of Electricity From the Global South. Cultural Anthropology (30:4): 555-568.

Hasenöhrl, Ute and Jonas van der Straeten 2016 (Introduction, this issue).

Hausman, William J., Peter Hertner and Mira Wilkins 2008. Global Electrification: Multinational Enterprise and International Finance in the History of Light and Power, 1878-2007. Cambridge: Cambridge University Press.

Headrick, Daniel R. 1981. The Tools of Empire: Technology and European Imperialism in the Nineteenth Century. Oxford: Oxford University Press.

Headrick, Daniel R. 1988. The Tentacles of Progress: Technology Transfer in the Age of Imperialism, 1850-1940. Oxford: Oxford University Press.

Hoag, Heather J. 2013. Developing the Rivers of East and West Africa: an Environmental History. London: Bloomsbury.

Hope-Simpson, John 1930. Report on Immigration, Land Settlement, and Development. URL: http://www.mideastweb.org/hopesimpson.htm (last accessed: 31.08.2016).

Hughes, Thomas P. 1983. Networks of Power: Electrification in Western Society 1880-1930. Baltimore: Johns Hopkins University Press.

Kale, Sunila S. 2014a. Structures of Power: Electrification in Colonial India. Comparative Studies of South Asia, Africa and the Middle East (34:3): 454-475.

Kale, Sunila S. 2014b. Electrifying India: Regional Political Economies of Development. Stanford, CA: Stanford University Press.

Kline, Ronald R. 2000. Consumers in the Country: Technology and Social Change in Rural America. Baltimore: Johns Hopkins University Press.

Marquez, Quevedo J. 2010. Telecommunications and Colonial Rivalry: European Telegraph Cables to the Canary Islands and Northwest Africa, 1883-1914. Historical Social Research (35:1): 108-124.

Mitchell, Timothy and Anupama Rao 2014. Introduction: Life of Infrastructure. Comparative Studies of South Asia, Africa and the Middle East (34:3): 437-439.

Naor, Mordecai 2003. The Gift of Electricity. Jerusalem: Ben-Zvi [in Hebrew].

Nye, David 1990. Electrifying America: Social Meanings of a New Technology. Cambridge, MA: MIT Press.

Peel, William (1st Earl) 1937. League of Nations Mandates Palestine Report of the Palestine Royal Commission. URL: https://unispal.un.org/pdfs/Cmd5479.pdf (last accessed: 31.08.2016).

Phillip, Akpen 2005. Electricity and Water Supply in Colonial Nigeria: A Case Study of Makurdi Town (1927-1960). Journal of the Historical Society of Nigeria (16): 48-71.

Platt, Harold L. 1991. The Electric City: Energy and the Growth of the Chicago Area, 1880-1930. Chicago: Chicago University Press.

Pomeranz, Kenneth 2000. The Great Divergence: China, Europe, and the Making of the Modern World Economy. Princeton: Princeton University Press.

Prakash, Gyan 1999. Another Reason: Science and the Imagination of Modern India. Princeton, NJ: Princeton University Press.

Protschky, Susie 2012. The Empire Illuminated: Electricity, 'ethical' colonialism and enlightened monarchy in photographs of Dutch royal celebrations, 1898-1948. Journal of Colonialism and Colonial History (13): 3.

Rao, Narasimha D. 2015. Book Review: Electrifying India: Regional Political Economies of Development, by Sunita S. Kale (2014). The Journal of Development Studies (50:10): $1464-1465$.

Rao, Srinivasa Y. 2010. Electricity, Politics and Regional Economic Imbalance in Madras Presidency, 1900-1947. Economic and Political Weekly (45): 59-66.

Rao, Srinivasa Y. and John Lourdusamy 2010. Colonialism and the Development of Electricity: The Case of Madras Presidency, 1900-1947. Science, Technology and Society (15:1): $27-54$.

Reguer, Sara 1995. Rutenberg and the Jordan River: A Revolution in Hydro-Electricity. Middle Eastern Studies (31:4): 691-729.

Reichman, Shalom, Yossi Katz and Yair Paz 1997. The Absorptive Capacity of Palestine, 1882-1948. Middle Eastern Studies (33:2): 338-361.

Schivelbusch, Wolfgang 1995. Disenchanted Night: The Industrialization of Light in the Nineteenth Century. Berkeley: University of California Press. 
Shaltiel, Eli 1990. Pinhas Rutenberg: 1879-1942, Life and Times. Tel Aviv: Am Oved.

Shamir, Ronen 2013. Current Flow: The Electrification of Palestine. Stanford: Stanford University Press.

Shamir, Ronen and Dafna Hacker 2001. Colonialism's Civilizing Mission: The Case of the Indan Hemp Drugs Commission. Law and Social Inquiry (26:2): 435-461.

Showers, Kate B. 2011. Electrifying Africa: An Environmental History with Policy Implications. Geografiska Annaler: Series B, Human Geography (93:3): 193-221.

Smith, Barbara J. 1993. The Roots of Separatism in Palestine: British Economic Policy 1920-1929. London: Tauris.

Speyer, H. R. 1915. The Development of Electric Power for Industrial Purposes in India. Journal of the Institution of Electrical Engineers (53): 597-604.

Steinmetz, George 2007. The Devil's Handwriting: Precoloniality and the German Colonial State in Qingdao, Samoa, and Southwest Africa. Chicago: The University of Chicago Press.

Straeten, Jonas van der 2014. Electricity in Colonial German East Africa and British Tanganyika Territory, 1908-1950. URL: https://tanzaniaelectricityhistory.wordpress.com/ category/texts-and-chapters/ (last accessed: 16.01.2016).

Straeten, Jonas van der 2015a. Legacies of a Past Modernism - Discourses of Development and the Shaping of Centralized Electricity Infrastructures in Late- and Postcolonial Tanzania'. In: Proceedings of the International Symposium Next Generation Infrastructure, 30 September-1 October 2014, Vienna.

Straeten, Jonas van der 2015b. Electrification in Tanzania from a Historical Perspective Discourses of Development and the Marginalization of the Rural Poor. In: Micro Perspectives for Decentralized Energy Supply: Proceedings of the International Conference at the BMS College of Engineering, Bangalore April 23rd to 25th, 2015. Berlin: Universitätsverlag der TU Berlin: 156-161.

Suvobrata, Sarkar 2015. Domesticating Electric Power: Growth of Industry, Utilities and Research in Colonial Calcutta. The Indian Economic and Social History Review (52:3): $357-389$.

Tinker, Hugh [1954] 1968. The Foundations of Local Self-Government in India, Pakistan, and Burma. London: Pall Mall Press.

Trottier, Julie 1999. Hydropolitics in the West Bank and Gaza Strip. Jerusalem: PASSIA, Palestinian Academic Society for the Study of International Affairs.

Winther, Tanja 2008. The Impact of Electricity: Development, Desires and Dilemmas. Oxford: Berhahn Books.

Ronen Shamir

Sociology and Anthropology Department

Tel Aviv University Ramat-Aviv

Tel Aviv

Israel

shamirr@post.tau.ac.il 